\title{
Response of some durum wheat genotypes (Triticum durum Desf.) for potassium fertilization levels in newly reclaimed soil.
}

\author{
Yasser A. M. Hefny \\ Agronomy Dept., Fac. Agric., Sohag Univ. \\ Correspondence::elhefniy@yahoo.com - Yasser.hefny@agr.sohag.edu.eg
}

Received on: 25-1-2021

Accepted on: 1-3-2021

\begin{abstract}
The properamount of fertilizer application is the main factor affecting thegrainyield and its components of durum wheat. Hence, the field experiment was carried out in the tow growing seasons of 2017/2018 andits reported in 2018/2019, at Research Farmof Faculty of Agriculture, Sohag University,to study the effects of potassium fertilizer levels (zero, 25, 50 and $75 \mathrm{~kg} \mathrm{~K}_{2} \mathrm{O} / \mathrm{fed}$.) on yield and its components of four durum wheat genotypes (BaniSuef 6,NGB 7214, NGB 5399 and NGB 4816). A randomized complete block design (RCBD) was used in split-plot with three replicates. The results showed that potassiumfertilizer levels were significantly effectedon all studied characters except plant height in the firstand second seas ons, and harvest index in the firstseason only.As well as genotypes had significantly effecton the all studied traits; plant height $(\mathrm{cm})$, spike length $(\mathrm{cm})$, No. of Spikes $/ \mathrm{m}^{2}$, No. of grains/spike ,1000-grain weight $(\mathrm{g})$, grain yield (ard./fed.), biological yield (ton/fed.), straw yield (ton/fed.) and harvest index(\%) in both growing seasons. Increasing K up to 75 $\mathrm{kgK}_{2} \mathrm{O} /$ fed.increased yield and its attributes of durum wheat in both growing seas ons except plant height $(\mathrm{cm})$ in the first and second seasons, and harvest index (\%)in the firs tseason only.BaniSuef 6 and NGB 7214 genotypes produced thehighest values of grain yield compared to other genotypes in both seasons. Moreover, NGB 7214 accession produced the maximum values of spike length $(\mathrm{cm})$, No. of Spikes $/ \mathrm{m}^{2}$, No.of grains/spike, 1000-grain weight $(\mathrm{g})$, biological yield (ton/fed.) and straw yield (ton/fed.) in the first and second seasons, res pectively, while NGB 7214, NGB 5399 and NGB 4816 accessions produced the tallest plants comparing with the Egyptian variety (BaniSuef 6). Interaction effect showed significant differences on all studied traits.In general, the highest grain yield (20.27 and 19.70ard./fed.) were obtained fromBaniSuef 6 genotype when fertilized with $75 \mathrm{kgK}_{2} \mathrm{O}$ /fed., andNGB 7214 genotype when fertilized with $50 \mathrm{~kg} \mathrm{~K}_{2} \mathrm{O} / \mathrm{fed}$.
\end{abstract}

KEYWORDS: Durum wheat genotypes, potassium fertilizer levels, and grain yield.

\section{INTRODUCTION}

For sustainable development, food security is one of most important issues facing the Egyptian government in all its various sectors (Assenget al. 2018). Wheat crop isconsideredthe staple food and the first grain crop in Egypt. Wheat grains are used as human food and straw is used as animal feed. Durum wheat (Triticum durum), a tetraploid species, it is an important crop for human consumption, being used to make pasta, bulgur and couscous. The high quality of durum wheat productsit depends on the properties of the grains. Among the influencing factors on the quality of the grain are fertilization, genotype and possible interactions among these factors (Bouachaet al. 2014). Wheat cultivated area is 1.26 million hectares with an average grain yield of 18.46 (ard. /fed)with a totalyield of approximately 8.1 million tons, but still there is a big gap about $50 \%$, between production and consumption(Abdelmageedet al. 2019).So, theEgyptiangovernment is faced to increase wheat productionin two strategies. The first one is the vertical expansion in valley land through the application of modern technologies(modern irrigation system, high yielding varieties, drainage improvement). Mainly these lands are exhausted from nutrient elements deficiency, especially the potassium and phosphors, due to increasing the crop intensity rate in the past decades. The second strategy is horizontal expansion through cultivate wheat crops in newly reclaimed land (Afafet al.2014), which suffers from low fertility and low water storage capacity, herein nutrientsadditionto the crop is considered one of the main factors, that affect yield and the quality(Hamoudaet al.2015).Potassiumis one of the major nutrient elements which affects yield and quality of grain,it is involved in many physiological processes, and its effect on water relationships, photosynthesis, transport assimilation, and enzyme activation can have direct consequences for crops productivity by opening and organizing stomata close 
thus regulating moisture lossfrom the plant.Sufficient amounts of potassium result in stronger wheat straw and assist in grain filling(Agri-News, 2012).Potassium elementdeficiency leads to decrease in both the numberof leaves productionand the size of individual leaves. Potassium plays asorganizational roles in the plant. The nutrients are lost from the soil in a number of ways, including leaching, volatilization, and fixation with clay minerals. High amounts of nutrients are absorbedfrom the soil into the dry matter of the harvested crops.Tabatabaeiet al. (2014)found that effect of different levels of potassium sulfate (Control, $80 \mathrm{~kg} / \mathrm{ha}, 130 \mathrm{~kg} / \mathrm{ha}$ and $160 \mathrm{~kg} / \mathrm{ha}$ ) was significant effecton number of spikes per $\mathrm{m}^{2}$, number of grains per spike, number of spikelets per spike, protein content, biological yield, grain yield and straw yield.With regard to the application of modern technologies in agriculture, increased productivity can be achieved through selecting high-yielding wheat varieties and applying appropriate agricultural practices such as fertilization rates (Khaled and Hammad 2014).

The current investigation laid out to study the response of some durum wheat genotypes for potassium fertilization under newly reclaimed soil conditions.

\section{MATERIALS AND METHODS}

The current investigation was carried out in the winter seasons of 2017/2018 and 2018/2019, at Research Farm of Faculty of Agriculture, Sohag University. Four durum wheat genotypes included BaniSuef 6cultivar and three genotypes i.e.NGB 7214, NGB 5399 and NGB 4816 were imported at 2010 from Nordic Genetic Resource Center (Nord Gen) then, after adapted under Sohag conditions, were used to study their responded to four potassium fertilizer levels (zero, 25, 50 and $75 \mathrm{~kg} \mathrm{~K}_{2} \mathrm{O} / \mathrm{fed}$.).

A randomized complete block design (RCBD) was usedin split-plot with three replications .The potassium fertilizer levels distributed randomly in the main plots; meanwhile durum wheat genotypes were laid out in the sub-plots. This experiment was included 48 experimental units, plots area was $10.5 \mathrm{~m}^{2}(3.5 \mathrm{~m}$ length $\times 3.0 \mathrm{~m}$ width), consisting of 15 rows with 20 $\mathrm{cm}$ apart between them. Seeding rate was used as recommended $(60 \mathrm{~kg} / \mathrm{fed}$.).Potassium fertilizer was added in potassium sulfateform $\left(48 \% \mathrm{~K}_{2} \mathrm{O}\right)$. Nitrogen fertilizer was added in the ammonium nitrate $(33.5 \%$ $\mathrm{N})$ at $100 \mathrm{~kg} \mathrm{~N} / \mathrm{fed}$. Phosphorus was added before sowing in superphosphate form $\left(15.5 \% \quad \mathrm{P}_{2} \mathrm{O}_{5}\right)$. All other agriculture practices were carried out as recommended.The experiment soil was sandy- loam;some properties of soil surface are shown in Tables (1).

Table 1. some properties of the experimentalsoil surface in $2017 / 2018$ and $2018 / 2019$ seasons.

\begin{tabular}{|c|c|c|}
\hline Soil properties & $2017 / 2018$ & $2018 / 2019$ \\
\hline Sand $(\%)$ & 68.66 & 67.54 \\
\hline Silt (\%) & 21.70 & 21.50 \\
\hline Clay $(\%)$ & 9.64 & 10.96 \\
\hline Soil texture & Sandy-loam & Sandy-loam \\
\hline $\mathrm{pH}(1: 2.5)$ & 8.1 & 7.8 \\
\hline $\mathrm{EC}(\mathrm{ds} / \mathrm{m})(1: 2.5)$ & 0.67 & 0.72 \\
\hline Organic matter(\%) & 1.73 & 1.81 \\
\hline Total N (\%) & 0.14 & 0.16 \\
\hline P2O5（ppm) & 18 & 17.4 \\
\hline $\mathrm{K} 2 \mathrm{O}$ (ppm) & 270 & 275 \\
\hline $\begin{array}{l}\text { Available } \\
\text { (ppm) }\end{array}$ & 2.86 & 3.00 \\
\hline $\begin{array}{l}\text { Available } \\
\text { (ppm) }\end{array}$ & 0.79 & 0.81 \\
\hline AvailableMn(ppm) & 0.34 & 0.42 \\
\hline $\begin{array}{l}\text { Available } \\
\text { (ppm) }\end{array}$ & 0.58 & 0.60 \\
\hline
\end{tabular}

\subsection{Data recorded:}

The following characters were recorded:Grain yield and its components (Plant height $(\mathrm{cm})$, Spike length $(\mathrm{cm})$, No. of grains/spike, No. of spikes $/ \mathrm{m}^{2}, 1000$-grain weight (g)and harvest index $\%)$ were recorded as recommended procedure. Biological and grain yields were recorded by weighing all above ground dry matter of each plot, then grain separating and weighing was done in kilograms and converted into ton and ard./fed., respectively.

\section{RESULTS AND DISCUSSIONS}

\subsection{Effect of potassium levels(A):}

Potassium is one of the major nutrients beside nitrogen and phosphorous (Fageria 2016). Potassium is necessary for various biochemical and physiological processes responsible for plant growth and development. Potassium is involved in protein synthesis, carbohydrate metabolism, and enzyme activation (Wanget al.2013).

Yield and yield component straits as influenced by level of $\mathrm{K}$ have been presented in Tables(2\&3). All the studied characters were signific antly influenced by different levels of K, with exception of plant height in both seasons and harvest indexin the first season did not affected signific antly. Spike length was increased signific antly by any of $\mathrm{K}$ fertilizer levels comparing with control treatment; 


\section{Scientific Journal of Agricultural Sciences 3 (1): 66-78, 2021}

meanwhile it was not significantly affected by increasing $\mathrm{K}$ levels from 25 up to $75 \mathrm{~kg} \mathrm{~K}_{2} \mathrm{O} /$ fed. in both seasons. The highest values of spike length $(9.84$ and $10.52 \mathrm{~cm})$ were observed in plots fertilized with $75 \mathrm{~kg} \mathrm{~K}_{2} \mathrm{O} / \mathrm{fed}$.in both seasons. However, the lowest spikes length $(8.78$ and $9.34 \mathrm{~cm})$ was observed in control treatment. No. of spikes $/ \mathrm{m}^{2}$ and grain yield (ard./fed.) were increased signific antly with increasing $\mathrm{K}$ fertilizers from zero till $75 \mathrm{~kg} \mathrm{~K} \mathrm{~K}_{2} \mathrm{O} /$ fed.in both seasons. Whereas the highest numbers of spikes $/ \mathrm{m}^{2}$ (370.25 and 374.25) and maximum grain yield/fed were (16.94 and 17.96 ard./fed) in the first and second seasons, respectively. These finding confirmed by the highly significant correlation between No. of spikes $/ \mathrm{m}^{2}$ and grain yield $(\mathrm{r}=0.90$ and 0.88$)$ in the first and second seasons respectively (Table 4). Moreover, No. of grains/spike responded significantly to $\mathrm{K}$ fertilizer from zero (control) up to 25 and $50 \mathrm{~kg} \mathrm{~K}_{2} \mathrm{O}$ /fed.in the first and second seasons, respectively, also further increasing of $\mathrm{K}$ fertilizer after $25 \mathrm{~kg} \mathrm{~K}_{2} \mathrm{O} /$ fed. did not affect 1000-grain weight in both seasons. While did not found any significant increasing of No. of grains/spike and 1000-grain at the highest $\mathrm{K}$ fertilizer levels in both seasons. Furthermore the highest significant means were69.75 at $\left(25 \mathrm{~kg} \mathrm{~K} \mathrm{~K}_{2} \mathrm{O}\right.$ /fed.) and 78.48 grains/spike at $\left(50 \mathrm{~kg} \mathrm{~K}_{2} \mathrm{O} /\right.$ fed.) and (43.88 and $45.13 \mathrm{~g}$ ) at $25 \mathrm{~kg} \mathrm{~K} \mathrm{~K}_{2} \mathrm{O} /$ fed.for No. of grains/spike and 1000-grain weight in the first and second seasons, respectively. No further significant increasing were found for both of biological and straw yields were found after $50 \mathrm{~kg} \mathrm{~K} / \mathrm{O} / \mathrm{fed}$. $\mathrm{K}$ levels in the first season, as well as the $25 \mathrm{kgK}_{2} \mathrm{O} /$ fed. level had none significantly difference on biological and straw yield comparing with control treatments but both of 50 and $75 \mathrm{~kg} \quad \mathrm{~K}_{2} \mathrm{O} / \mathrm{fed}$. $\mathrm{K}$ levels had significantly difference in the same way in the second seasons comparing with control and $25 \mathrm{~kg}$ levels. The result indicated that the cumulative effect of yield contributing characters, such as No .of spike $/ \mathrm{m}^{2}$, No.of grains/spike, and 1000-grain weight had positive contribution to higher grain yield obtained till $50 \mathrm{~kg}$ $\mathrm{K}_{2} \mathrm{O}$ /fed. This is confirmed by the highly significant positive correlation coefficients of grain yield $(0.90$, 0.86 and 0.82$)$ and $(0.88,0.87$ and 0.79$)$ by No.of spikes $/ \mathrm{m}^{2}$, No. grains/spike and 1000-grain weight in the first and second season respectively (Table 4).In case of control, the grow th and development of plants were hampered due to imbalance uptake of potassium element which resulted in poor performance of yield attributes and ultimately gave the lowest grain yield (Alamet al.2009).

Harvest index indicates the physiological ability to transform photosynthesis of the grain yield.
Data regarding harvest index (Tables2\&3) was insignificant influenced by different levels of $K$ in the first season due to application of different potassium levels. The maximum harvest index $(50.28 \%)$ was recorded from the plots fertilized with $25 \mathrm{~kg} \mathrm{~K}_{2} \mathrm{O} /$ fed. in the second season. Potassium fertilizer levels had signific ant effect on yield and its components of wheat might be due to the balanced accumulation of different nutrient elements in the grain resulting higher grain weight (El-Hamdiet al.2019). Potassium is an important essential element for plant growth and physiology, its impact on photosynthesis, water relations, enzyme activation and assimilate transport can have direct consequences on productivity of crop (Pettigrew, 2008).Potassiumis not only a component of plant structure but it also has a regulatory function in many biochemical processes related to protein synthesis, Carbohydrate metabolism, enzyme activation. Many physiological processes depend on such as stomatal regulation and photosynthesis (Hasanuzzaman et al. 2018). Hamouda et al. (2015) illustrate that the application of the potassium fertilization levels had an increased significant effect on the yield and its components of the wheat plant (number of spikes, straw, grain yield, biological yield, and 1000 grain weight) compared to the control. Potassium fertilization at a rate of $100 \%$ and $75 \%$ increase the most of the grow th and yield components and the accumulation of nutrients in the wheat crop from $20-50 \%$ and $8-40 \%$. However, using potassium at 50 and $25 \%$ increased grow th components and yield by $4-20 \%$ compared to control (Kubar et al.2019). The same conclusion was reported by Arabi et al.(2002), Alam et al. (2009), Maurya et al.(2014), Hamouda et al. (2015) and El-Defan et al.(2016).

\subsection{Effect of genotypes (B):}

The increasing yield was achieved through selection of wheat varieties are resistant to lodging, high response to mineral fertilizers, long spike, and medium or early maturing (Abdel mageed et al. 2019). Data in Tables (2\&3) showed significant differences between durum varieties in all studied traits in both seasons. The imported genotypes (NGB 7214, NGB 5399 and NGB 4816) were increased significantly by $25.64,26.25$ and $24.32 \%$ and $23.61,23.43$ and 24.28 $\%$ in plant height comparing with the Egyptian variety (BaniSuef6) in the first and second seasons respectively. 
Yasser A. M. Hefiny., 2021

Table 2. Means of studied traits under potassium(A)fertilization levels of durum wheat genotypes(B) in 2017/2018.

\begin{tabular}{|c|c|c|c|c|c|c|c|c|c|c|}
\hline $\begin{array}{l}\text { Potassium } \\
\text { level }\end{array}$ & Varieties & $\begin{array}{c}\text { Plant } \\
\text { height } \\
(\mathrm{cm})\end{array}$ & $\begin{array}{l}\text { Spike } \\
\text { length } \\
(\mathrm{cm})\end{array}$ & $\begin{array}{c}\text { No. of } \\
\text { Spike } \\
/ \mathrm{m}^{2}\end{array}$ & $\begin{array}{c}\text { No. of } \\
\text { grain/spike }\end{array}$ & $\begin{array}{l}\text { 1000-grain } \\
\text { weight (g) }\end{array}$ & $\begin{array}{c}\text { Grain } \\
\text { yield } \\
\text { (ardab/fed.) }\end{array}$ & $\begin{array}{c}\text { Biological } \\
\text { yield (ton/fed.) }\end{array}$ & $\begin{array}{c}\text { Straw } \\
\text { yield } \\
\text { (ton/fed.) }\end{array}$ & $\begin{array}{c}\text { Harvest } \\
\text { index } \\
(\%)\end{array}$ \\
\hline & V1 & 79.47 & 6.73 & 276.67 & 49.23 & 38.83 & 11.42 & 2.93 & 1.22 & 60.70 \\
\hline Zero & $\mathbf{V 2}$ & 103.33 & 10.37 & 327.33 & 59.03 & 42.93 & 12.81 & 3.80 & 1.89 & 51.29 \\
\hline \multirow[t]{4}{*}{ (control) } & V3 & 96.63 & 9.67 & 319.00 & 51.33 & 41.16 & 11.78 & 3.33 & 1.56 & 53.43 \\
\hline & V4 & 106.93 & 8.37 & 291.33 & 50.70 & 40.85 & 11.73 & 3.90 & 2.14 & 45.83 \\
\hline & Mean & 96.09 & 8.78 & 303.58 & 52.56 & 40.95 & 11.93 & 3.49 & 1.70 & 52.81 \\
\hline & V1 & 78.73 & 8.23 & 316.33 & 68.03 & 42.27 & 12.86 & 3.32 & 1.40 & 58.68 \\
\hline \multirow[t]{5}{*}{$25 k_{2} 0$ / fed. } & $\mathbf{V 2}$ & 105.90 & 10.43 & 360.67 & 73.00 & 46.83 & 14.89 & 4.24 & 2.01 & 52.83 \\
\hline & $\mathbf{V 3}$ & 103.13 & 10.67 & 333.67 & 69.23 & 43.67 & 14.61 & 4.16 & 1.97 & 52.78 \\
\hline & V4 & 108.70 & 9.23 & 295.67 & 68.73 & 42.73 & 13.73 & 3.67 & 1.61 & 56.49 \\
\hline & Mean & 99.12 & 9.64 & 326.58 & 69.75 & 43.88 & 14.02 & 3.85 & 1.75 & 55.20 \\
\hline & V1 & 82.73 & 9.30 & 367.00 & 73.30 & 45.03 & 15.74 & 4.81 & 2.45 & 49.31 \\
\hline \multirow[t]{6}{*}{$50 k_{2} \mathrm{o} /$ fed. } & $\mathbf{V 2}$ & 109.07 & 11.70 & 392.33 & 81.20 & 49.73 & 18.68 & 5.18 & 2.38 & 54.25 \\
\hline & V3 & 113.05 & 9.43 & 355.66 & 71.20 & 43.33 & 15.44 & 4.49 & 2.18 & 51.84 \\
\hline & V4 & 96.87 & 8.50 & 321.33 & 72.87 & 41.89 & 14.72 & 3.93 & 1.72 & 56.91 \\
\hline & Mean & 100.43 & 9.73 & 359.08 & 74.64 & 45.00 & 16.15 & 4.60 & 2.18 & 53.08 \\
\hline & V1 & 92.93 & 9.77 & 408.00 & 79.73 & 50.87 & 19.55 & 5.11 & 2.18 & 57.39 \\
\hline & V2 & 101.17 & 11.63 & 394.00 & 78.40 & 49.80 & 18.39 & 4.87 & 2.11 & 56.69 \\
\hline \multirow[t]{3}{*}{$75 k_{2} o$ / fed. } & V3 & 108.70 & 9.43 & 355.67 & 70.76 & 43.28 & 15.18 & 4.62 & 2.34 & 49.43 \\
\hline & V4 & 92.57 & 8.53 & 323.33 & 67.87 & 40.67 & 14.62 & 3.85 & 1.66 & 57.62 \\
\hline & Mean & 98.84 & 9.84 & 370.25 & 74.19 & 46.15 & 16.94 & 4.61 & 2.07 & 55.28 \\
\hline \multirow[t]{4}{*}{ Mean } & V1 & 83.47 & 8.51 & 342.00 & 67.56 & 44.25 & 14.89 & 4.04 & 1.81 & 56.52 \\
\hline & $\mathbf{V 2}$ & 104.87 & 11.03 & 368.58 & 72.91 & 47.33 & 16.19 & 4.52 & 2.10 & 53.77 \\
\hline & V3 & 105.38 & 9.80 & 341.00 & 65.63 & 42.87 & 14.25 & 4.15 & 2.01 & 51.87 \\
\hline & V4 & 103.77 & 8.66 & 307.92 & 65.04 & 41.54 & 13.70 & 3.84 & 1.78 & 54.21 \\
\hline \multirow[t]{3}{*}{ LSD 5\% } & $\begin{array}{l}\text { potassium } \\
\text { levels }(\mathrm{A})\end{array}$ & - & 0.59 & 12.50 & 3.04 & 3.00 & 0.45 & 0.36 & 0.31 & - \\
\hline & $\begin{array}{l}\text { genotypes } \\
\text { (B) }\end{array}$ & 2.81 & 0.73 & 8.07 & 2.50 & 0.88 & 0.54 & 0.46 & 0.29 & 3.94 \\
\hline & AxB & 5.62 & 1.47 & 16.15 & 5.00 & 1.76 & 1.08 & 0.91 & 0.77 & 9.87 \\
\hline
\end{tabular}

V1:BaniSuef $6 \quad$ V2:NGB $7214 \quad$ V3:NGB $5399 \quad$ V4:NGB 4816 LSD :Least significant difference at 5\%. 
Scientific Journal of Agricultural Sciences 3 (1): 66-78, 2021

Table 3. Means of studied traits under potassium fertilization levels(A) of durum wheat genotypes(B) in in $2018 / 2019$.

\begin{tabular}{|c|c|c|c|c|c|c|c|c|c|c|}
\hline $\begin{array}{c}\text { Potassium } \\
\text { level }\end{array}$ & Varieties & $\begin{array}{c}\text { Plant } \\
\text { height } \\
(\mathbf{c m})\end{array}$ & $\begin{array}{c}\text { Spike } \\
\text { length } \\
(\mathrm{cm}) \\
\end{array}$ & $\begin{array}{c}\text { No. of } \\
\text { Spike } \\
/ \mathbf{m}^{2} \\
\end{array}$ & $\begin{array}{c}\text { No. of } \\
\text { grain/spike }\end{array}$ & $\begin{array}{c}\text { 1000-grain } \\
\text { weight (g) }\end{array}$ & $\begin{array}{c}\text { Grain } \\
\text { yield } \\
\text { (ardab/fed.) }\end{array}$ & $\begin{array}{c}\text { Biological } \\
\text { yield (ton/fed.) }\end{array}$ & $\begin{array}{c}\text { Straw } \\
\text { yield } \\
\text { (ton/fed.) } \\
\end{array}$ & $\begin{array}{c}\text { Harvest } \\
\text { index } \\
(\%)\end{array}$ \\
\hline & V1 & 81.57 & 7.23 & 284.33 & 52.90 & 39.83 & 12.21 & 3.80 & 1.96 & 49.00 \\
\hline Zero & $\mathbf{V} 2$ & 103.30 & 10.93 & 334.00 & 63.03 & 44.03 & 13.59 & 4.67 & 2.63 & 43.91 \\
\hline \multirow[t]{4}{*}{ (control) } & V3 & 95.27 & 10.20 & 325.67 & 54.67 & 42.23 & 12.87 & 4.17 & 2.24 & 46.44 \\
\hline & V4 & 106.40 & 9.00 & 301.67 & 54.37 & 41.35 & 12.67 & 4.47 & 2.57 & 42.97 \\
\hline & Mean & 96.13 & 9.34 & 311.42 & 56.24 & 41.87 & 12.83 & 4.27 & 2.35 & 45.58 \\
\hline & V1 & 81.90 & 8.83 & 328.33 & 70.37 & 43.07 & 13.94 & 3.94 & 1.85 & 53.90 \\
\hline \multirow[t]{5}{*}{$25 k_{2} 0 /$ fed. } & V2 & 107.37 & 11.03 & 367.00 & 76.33 & 47.63 & 15.87 & 4.86 & 2.48 & 49.38 \\
\hline & V3 & 103.63 & 11.23 & 349.00 & 72.23 & 45.20 & 15.69 & 4.77 & 2.42 & 49.57 \\
\hline & V4 & 111.10 & 9.90 & 304.33 & 69.73 & 44.60 & 14.68 & 4.57 & 2.37 & 48.26 \\
\hline & Mean & 101.00 & 10.25 & 337.17 & 72.17 & 45.13 & 15.05 & 4.53 & 2.28 & 50.28 \\
\hline & V1 & 84.33 & 9.83 & 369.00 & 77.63 & 45.73 & 16.72 & 5.65 & 3.15 & 44.49 \\
\hline \multirow[t]{6}{*}{$50 \mathrm{k}_{2} \mathrm{O} / \mathrm{fed}$. } & $\mathbf{V} 2$ & 109.75 & 12.30 & 400.33 & 83.87 & 50.83 & 19.70 & 5.97 & 3.02 & 49.58 \\
\hline & V3 & 113.63 & 10.13 & 366.33 & 75.87 & 44.27 & 16.40 & 5.48 & 3.02 & 45.00 \\
\hline & V4 & 103.40 & 9.13 & 331.33 & 76.53 & 42.92 & 15.81 & 5.02 & 2.64 & 47.78 \\
\hline & Mean & 102.78 & 10.35 & 366.75 & 78.48 & 45.94 & 17.16 & 5.53 & 2.96 & 46.71 \\
\hline & V1 & 94.63 & 10.50 & 416.33 & 83.07 & 51.47 & 20.27 & 6.05 & 3.01 & 50.25 \\
\hline & V2 & 102.87 & 12.27 & 397.00 & 82.37 & 50.37 & 19.44 & 5.75 & 2.84 & 50.79 \\
\hline \multirow[t]{3}{*}{$75 k_{2} 0 /$ fed. } & V3 & 110.13 & 10.03 & 362.33 & 76.77 & 44.23 & 16.43 & 5.34 & 2.88 & 46.33 \\
\hline & V4 & 93.67 & 9.26 & 321.33 & 72.20 & 41.83 & 15.72 & 4.99 & 2.63 & 47.51 \\
\hline & Mean & 100.33 & 10.52 & 374.25 & 78.60 & 46.98 & 17.96 & 5.53 & 2.84 & 48.72 \\
\hline \multirow[t]{4}{*}{ Mean } & V1 & 85.61 & 9.10 & 349.50 & 70.99 & 45.03 & 15.79 & 4.86 & 2.49 & 49.41 \\
\hline & V2 & 105.82 & 11.63 & 374.59 & 76.40 & 48.22 & 17.15 & 5.31 & 2.74 & 48.42 \\
\hline & V3 & 105.67 & 10.40 & 350.83 & 69.88 & 43.98 & 15.35 & 4.94 & 2.64 & 46.83 \\
\hline & V4 & 106.14 & 9.33 & 314.67 & 68.21 & 42.68 & 14.72 & 4.76 & 2.55 & 46.63 \\
\hline \multirow[t]{3}{*}{ LSD $5 \%$} & $\begin{array}{l}\text { potassium } \\
\text { levels (A) }\end{array}$ & - & 0.58 & 12.18 & 2.36 & 2.84 & 0.48 & 0.38 & 0.31 & 3.54 \\
\hline & $\begin{array}{l}\text { genotypes } \\
\text { (B) }\end{array}$ & 4.01 & 0.76 & 9.77 & 2.51 & 1.10 & 0.50 & 0.48 & 0.41 & 2.57 \\
\hline & AxB & 8.01 & 1.54 & 19.54 & 3.52 & 2.19 & 1.00 & 0.95 & 0.83 & 7.15 \\
\hline
\end{tabular}


Yasser A. M. Hefny., 2021

Table 4. Correlation coefficient between studied traitsin 2017/2018 (abovediagonal) and 2018/2019 (below diagonal).

\begin{tabular}{llllllllll}
\hline & PH & SL & NOS & NOG & TKW & BYD & GYD & ST & HI \\
\hline PH & & $0.33^{*}$ & 0.12 & 0.09 & 0.19 & $0.32^{*}$ & 0.14 & $0.40^{* *}$ & $-0.41^{* *}$ \\
SL & $0.31^{*}$ & & $0.62^{* *}$ & $0.52^{* *}$ & $0.62^{* *}$ & $0.48^{* *}$ & $0.55^{* *}$ & $0.34^{*}$ & -0.07 \\
NOS & 0.14 & $0.61^{* *}$ & & $0.79^{* *}$ & $0.849^{* *}$ & $0.789^{* *}$ & $0.909^{* *}$ & $0.55^{* *}$ & -0.08 \\
NOG & 0.15 & $0.51^{* *}$ & $0.79^{* *}$ & & $0.72^{* *}$ & $0.65^{* *}$ & $0.86^{* *}$ & $0.37 * *$ & 0.12 \\
TKW & 0.24 & $0.61^{* *}$ & $0.81^{* *}$ & $0.69^{* *}$ & & $0.67^{* *}$ & $0.82^{* *}$ & $0.43^{* *}$ & $0.29^{* *}$ \\
BYD & $0.30^{*}$ & $0.45^{* *}$ & $0.74^{* *}$ & $0.69^{* *}$ & $0.62^{* *}$ & & $0.85^{* *}$ & $0.92^{* *}$ & $-0.54^{* *}$ \\
GYD & 0.17 & $0.57^{* *}$ & $0.88^{* *}$ & $0.88^{* *}$ & $0.79^{* *}$ & $0.87^{* *}$ & & $0.5786^{* *}$ & $-0.04 \mathrm{~N} . \mathrm{S}$ \\
ST & $0.35^{*}$ & $0.31^{*}$ & $0.51^{* *}$ & $0.45^{* *}$ & $0.39^{* *}$ & $0.93^{* *}$ & $0.63^{* *}$ & & $-0.815^{* *}$ \\
HI & $-0.32^{*}$ & 0.10 & 0.14 & 0.25 & 0.21 & $-0.40^{* *}$ & 0.10 & $-0.69^{* *}$ & \\
\hline
\end{tabular}

PH: Plant height (cm), SL: Spike length (cm), NOS: No. of spikes $/ \mathrm{m}^{2}$,NOG: No. of grains/spike, TKW: 1000grain weight (g), BYD: Biological yield (ton/fed.), GYD: Grain yield (ardab/fed.), ST : Straw yield (ton/fed.),HI: harvest index \%).

Meanwhile the genotypes (NGB 7214 and NGB 5399) were superior significantly in spike length comparing with both of BaniSuef 6 and NGB 4816 in both seasons. Since the highest value of spike length $(11.03$ and $11.63 \mathrm{~cm})$ was exhibited by NGB7214 in the first and second season respectively. Regarding to No. of spikes $/ \mathrm{m}^{2}$, the genotypes NGB 7214 exhibited the highest number of spikes $/ \mathrm{m}^{2}$ (368.58 and 374.59) and increased significantly by 7.77 and $7.18 \%$ from the Bani Suef 6. In contrast the genotype NGB 4816 was the lowest No. of spikes $/ \mathrm{m}^{2}$ (307.92 and 314.67) and decreased significantly by 9.46 and $9.96 \%$ from the BaniSuef 6in the first and second season respectively. The NGB 7214 was superior signific antly in No. of grains/spike, 100-grain weight and grain yield/fed to the other genotypes, and exhibited the highest values (72.91 and 76.40 grains), (47.33 and $48.22 \mathrm{~g}$ ) and (16.19 and $17.15 \mathrm{ardab} / \mathrm{fed}$ )in the first and second seasons respectively, meanwhile the genotype NGB 4816 was more decreased signific antly than the others. Hence, the superiority of NGB7214genotype in grain yield/fed due to their ability to longest spikes, high spikes and grains numbers as well as high 1000-grain weight. Also these results explained by the significant positive correlations coefficients between grain yield $\mathrm{ardab} / \mathrm{fed}$. and both of spike length, No. of spikes $/ \mathrm{m}^{2}$, No. of grains/spike and 1000 -grain weight $(0.55,0.90$, 0.86 and 0.82$)$ and $(0.57,0.88,0.87$ and 0.79$)$ in the first and second seasons, respectively (Table 4). On the other hand, the genotype NGB 4816 was decreased significantly in the biological and straw yields/fed comparing with the other genotypes. The Egyptian variety (Bani Suef 6) was increased significantly in harvest index(56.52 and $49.41 \%)$ in the first and second seasons, respectively. Therefore this is due to the its lower grain yield. The highly differences among durum wheat genotypes could be due to the genetic make-up and their response to the environmental condition. Eman et al. (2011) showed that Beni Suef 6 variety surpasses of the other varietiesi.e Bani Suef 1, 3, 4, 5 and Sohag 3 in number of spikes $/ \mathrm{m}^{2}$, number of kernels/spike, higher 1000kernel weight and grain yield. The differences among durum wheat varieties were reported by Arduini et al. (2006),Emanet al. (2011), Gul et al. (2012) Belay et al. (2013), Upadhyay et al.(2015), Amalet al. (2016), Abdel mageed et al. (2019), EL -Hamdiet al.(2019) and El-Rawy (2020)

\subsection{Interaction between potassium levels $x$ genotypes $(\mathbf{A x B})$ :}

Data in Tables (2\&3) revealed that all studied traits affected significantly by potassium levels $\mathrm{x}$ genotypes interaction in both seasons. That is means the studied genotypes were responded in different ways to potassium fertilizer levels. The results show ed that the tallest plants $(113.05$ and $113.63 \mathrm{~cm})$ were observed by the genotype NGB 5399 when fertilized at $50 \mathrm{~kg} \mathrm{k}_{2} \mathrm{O} / \mathrm{fed}$.in the first and second seasons, respectively. Moreover, the highest values of spike length $(11.70 \& 11.63 \mathrm{~cm})$ and $(12.30 \& 12.37 \mathrm{~cm})$ were obtained by the genotype NGB 7214 when fertilized at 50 and $75 \mathrm{~kg} \mathrm{k}_{2} \mathrm{O} /$ fed.in the first and second seasons, that is means that the spike length of this genotypes was responded to $\mathrm{K}$ fertilizers up to 50 $\mathrm{kg} \mathrm{k}_{2} \mathrm{O} /$ fed. and no further increasing with the higher $\mathrm{K}$ levels. The highest values $(408,392.33$ and 394 spikes), (79.73, 81.20 and 78.40 grains), (50.87, 49.73 and $49.80 \mathrm{~g})$ and $(19.55,18.68$ and $18.39 \mathrm{ardab} / \mathrm{fed}$. were found in the interaction treatments of (Bani Suef $6+75 \mathrm{~kg} \mathrm{k}_{2} \mathrm{O} /$ fed.), (NGB $7214+50 \mathrm{~kg} \mathrm{k}_{2} \mathrm{O} /$ fed.)and 
(NGB 7214+ $75 \mathrm{~kg} \mathrm{k}_{2} \mathrm{O} / \mathrm{fed}$.) with insignificant differences amongeach other for No. of spikes $/ \mathrm{m}^{2}$, No. of grains/spike, 1000-grain weight and grain yield/fed in the first season, respectively. But the second season, the highest values (416.33, 400.33 and 397 spikes), (83.07, 83.87 and 82.37 grains), (51.47, 50.83 and $50.37 \mathrm{~g})$ and $(20.27,19.70$ and 19.44 ardab/fed.) were found in the same interaction treatments. These results are explained by the significant linear response of the Egyptian genotype Bani Suef 6 till the highest $\mathrm{k}$ fertilizer levels. Otherwise the genotype NGB 7214 was responded significantly up to $50 \mathrm{~kg} \mathrm{k}_{2} \mathrm{o} / \mathrm{fed}$. fertilizer level for the mentioned traits and no further signific ant response in the higher $\mathrm{k}$ levels, as well as for biological and straw yield. These finding may be due to the genetic ability of the imported genotype NGB 7214 in Kusage efficiently under these conditions.

The Figure1a\&b represents the linear regressions of grain yield on the $\mathrm{k}$ fertilizer levels for the genotype BaniSuef 6 (V1) and genotype NGB 7214 (V2), whereas the regression coefficients (b) were (2.70 and 2.14) and determination coefficient (R2) were 0.98 and 0.88 for V1 and V2 in both seasons. The $b$ and $R 2$ for No. of spikes $/ \mathrm{m}^{2}$ were 44.47 and 23.12 and 0.99 and 0.90 in the first season and (43.67 and 22. 20) and (0.999 and 0.86) in the second season for the genotype V1 and V2 respectively(Figure $2 \mathrm{a} \& \mathrm{~b}$ ). The regression coefficients were higher in the No. of grains/spike and 1000-grain weight for BaniSuef 6 (V1) than the genotype NGB 7214 (V2), in contrast the determination coefficients were lower for V1 than the V2 in both seasons (Figure 3 and Figure 4).Bouacha et al.(2014) found that Landraces (Chili, Biskri, Mahmoudi and INRAT69 )showed a better expression of protein content than high yielding cultivars(Karim,Razzak, Omrabiaa and Khiar) for all fertilizers combinations(nitrogen $(\mathrm{N})$ and potassium (K). Overall means of protein content were calculated for landraces and high yielding cultivars and they were $18.32 \%$ and $15.81 \%$,respectively

\section{CONCLUSION}

In light of the results of the research work that lasted for two years, it can be concluded that significant differences among four durum wheat genotypes for all studied traits under potassium fertilization levels. Maximum grain yield of the Egyptian variety (BaniSuef 6) was achieved when fertilized at $75 \mathrm{~kg} \mathrm{k}_{2} \mathrm{O} / \mathrm{fed}$, as well as the highest grain yield was obtained for the imported variety NGB 7214 was achieved when fertilized with $50 \mathrm{~kg} \mathrm{k}_{2} \mathrm{o} / \mathrm{fed}$. under the conditions of newly reclaimed soil.

\section{REFERENCES}

Abdel mageed K, Xu-hong C, De-mei1 W, Yan-jie W, Yu-shuang $Y$, Guang-cai $Z$, Zhi-qiang1 $\mathbf{T}(\mathbf{2 0 1 9})$. Evolution of varieties and development of production technology in Egypt wheat: A review. Journal of Integrative Agriculture, 18(3): 483495.

Afaf ZO, Nayera YS, Ahlam AH (2014). Study of the most important factors affecting the production of wheat crop in the new lands in Egypt (Nubaria Area).Middle East Journal of Agriculture Research, 3(1): 20-26.

Agri-News (2012). E-New sletter: Wheat nutrition and fertilizer requirements: potassium. Available from agric.gov.ab.ca/\$Department/deptdocs.nsf/All/

webdoc 7998. [November 4, 2015].

Alam MR, Ali MA, Molia MSH, Momin MA, Mannan MA (2009). Evaluation of different levels of potassium on the yield and protein content of wheat in the high gangesriver floodplain. Bangladesh Journal of Agriculture Research, 34(1) : 97-104.

Amal GMA, Omar MA, Nawar AI, El-Tabbakh SSh (2016).Effect of sowing date and nitrogen fertilization level on grow th and productivity of some durum and bread wheat varieties. Alexandria Science exchange Journal, 37(4):541-549.

Arabi MIE, Ali NM, Jawhar M (2002). Effect of foliar and soil potassium fertilization on wheat yield and severity of Septoriatritici blotch. Australasian Plant Pathol, 3: 359-362.

Arduini I, Masoni A, Ercoli L, Mariotti M (2006).Grain yield, and dry matter and nitrogen accumulation and remobilizationin durum wheat as affected by variety and seeding rate.Europe Journal of Agronomy, 25: 309-318.

Asseng S, Kheir AMS, Kassie BT, Hoogenboom G, Abdelaal AIN, Haman DZ, Ruane AC (2018). Can Egypt become self-sufficient in wheat? Environmental research letters. 13094012

Belay M, Dessaleng T, Bayu W (2013). Some Ethiopian Durum Wheat Varieties and their Use $\mathrm{N}$-use Efficiency. Lambert Academic publishing.

Bouacha OD, Nouaigui S, Rezgui S (2014) .Effects of $\mathrm{N}$ and $\mathrm{K}$ fertilizers on durum wheat quality in different environments. Journal of Cereal Science, 59 : 9-14.

El-Defan TA, El-Kholi HMA, Rifaat MGM, Allah AEA (2016). Effect of soil and foliar application of potassium on yield and mineral content of wheat grains grown in sandy soils. Egyptian Journal of Agriculture Research ,77: 513-522. 
Yasser A. M. Hefny., 2021
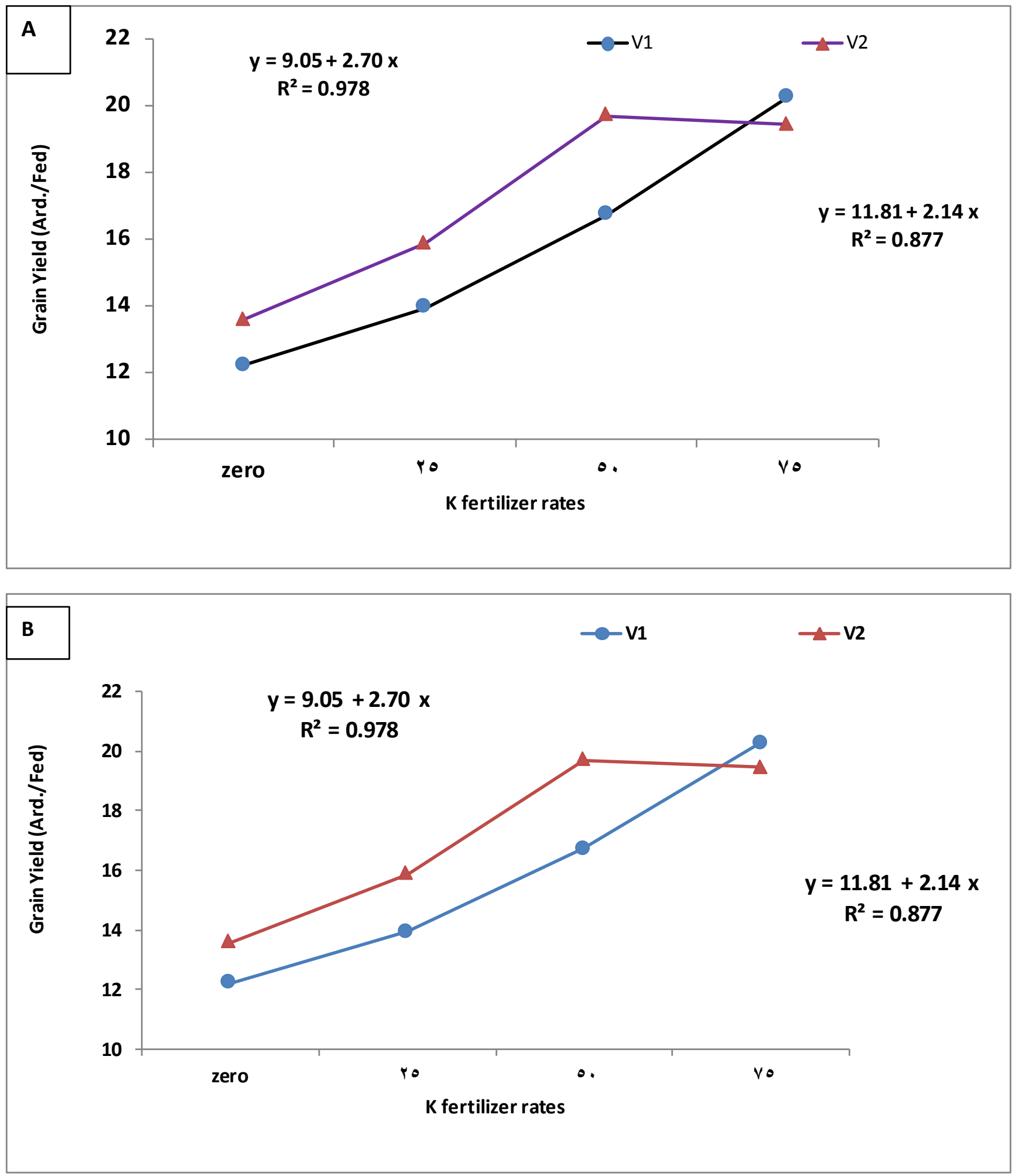

Figure 1. Linear response of grain yield (ard./fed.) for V1 and V2 in (A): 2017/2018 and (B): 2018/2019. 
Scientific Journal of Agricultural Sciences 3 (1): 66-78, 2021

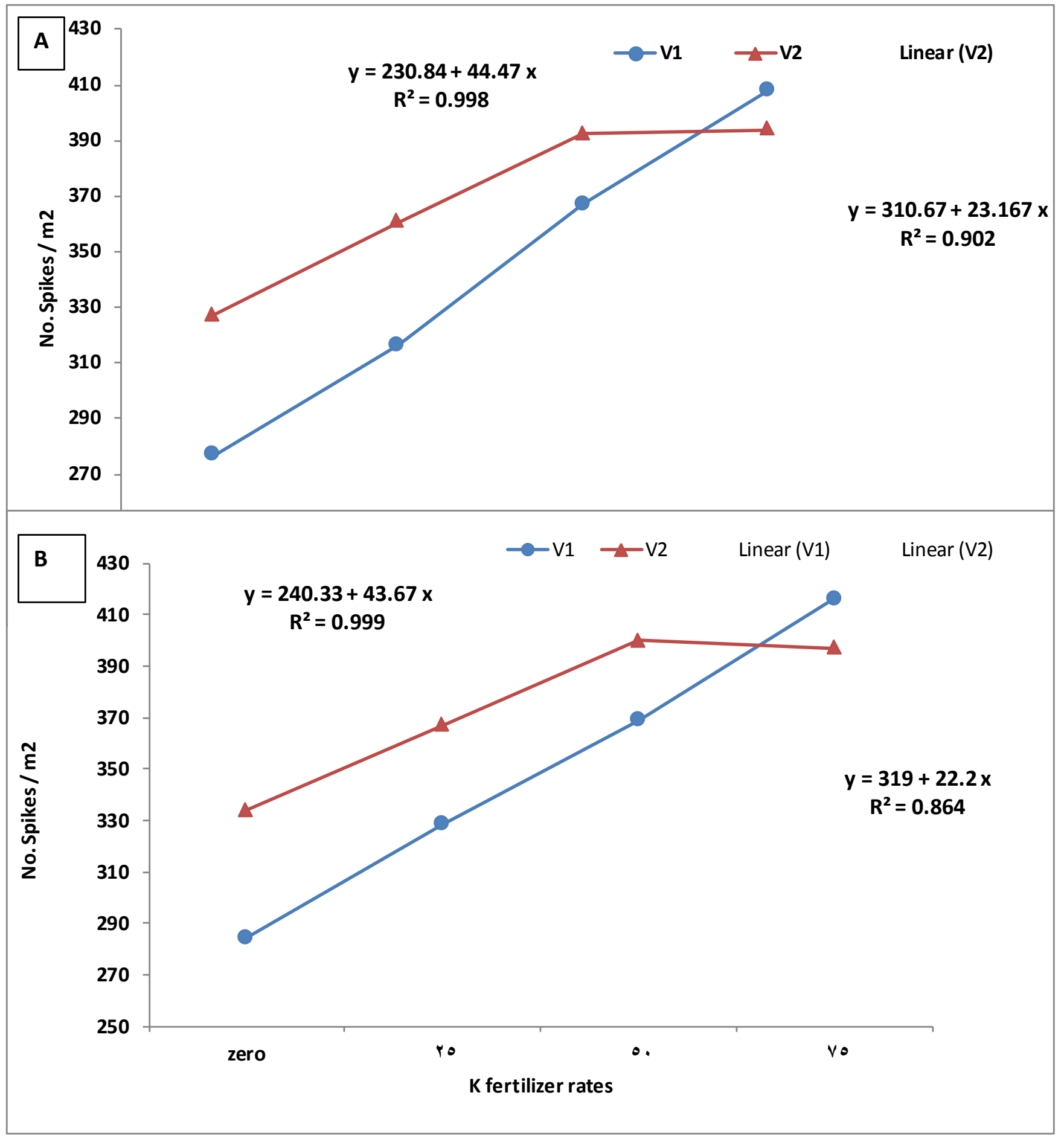

Figure 2. Linear response of spikes $/ \mathrm{m}^{2}$ for $\mathrm{V} 1$ and $\mathrm{V} 2$ in (A): 2017/2018 and (B): 2018/2019. 
Yasser A. M. Hefny., 2021

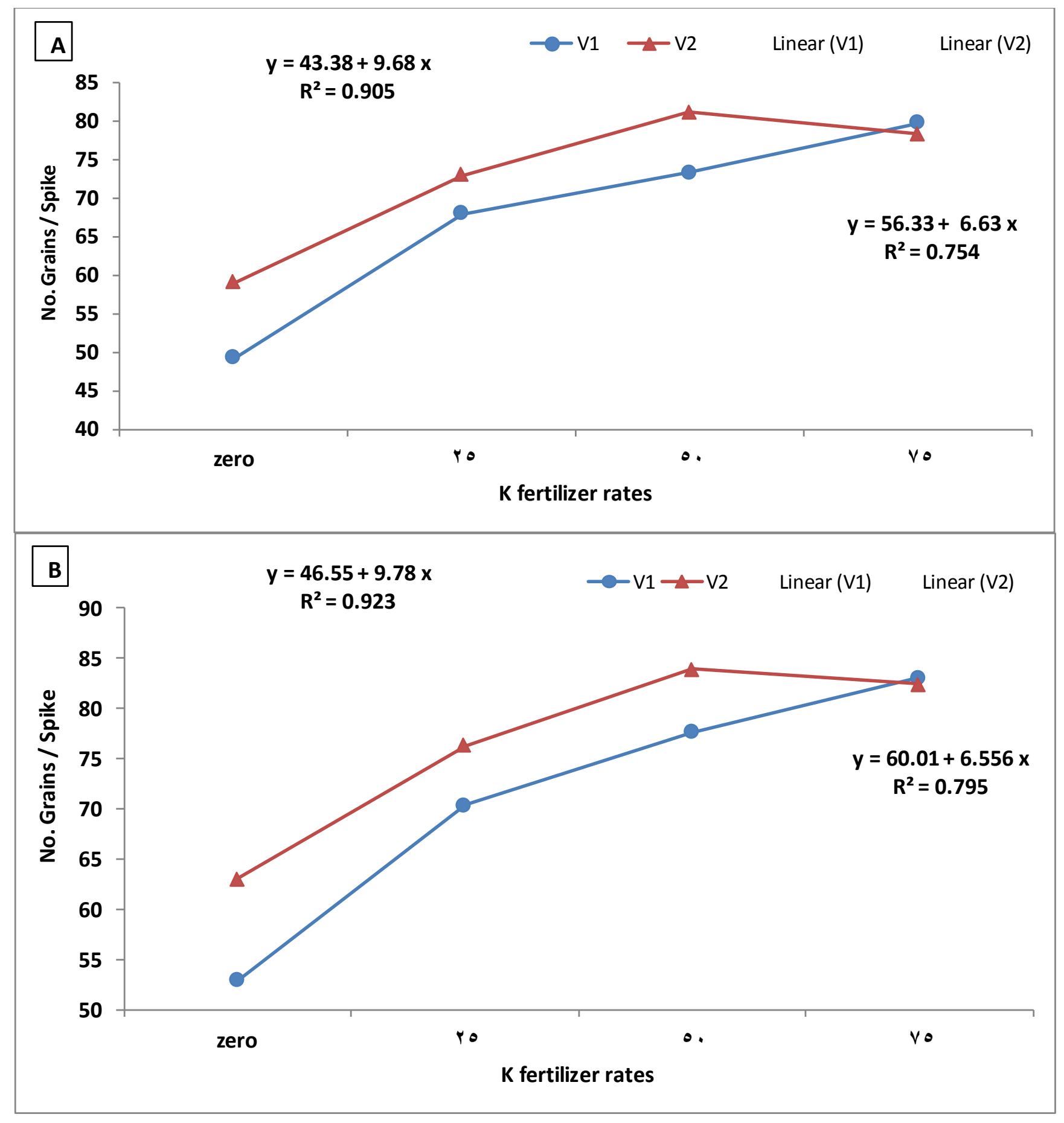

Figure 3. Linear response of No. of grains/spike for V1 and V2 in (A): 2017/2018 and (B): 2018/2019. 
Scientific Journal of Agricultural Sciences 3 (1): 66-78, 2021
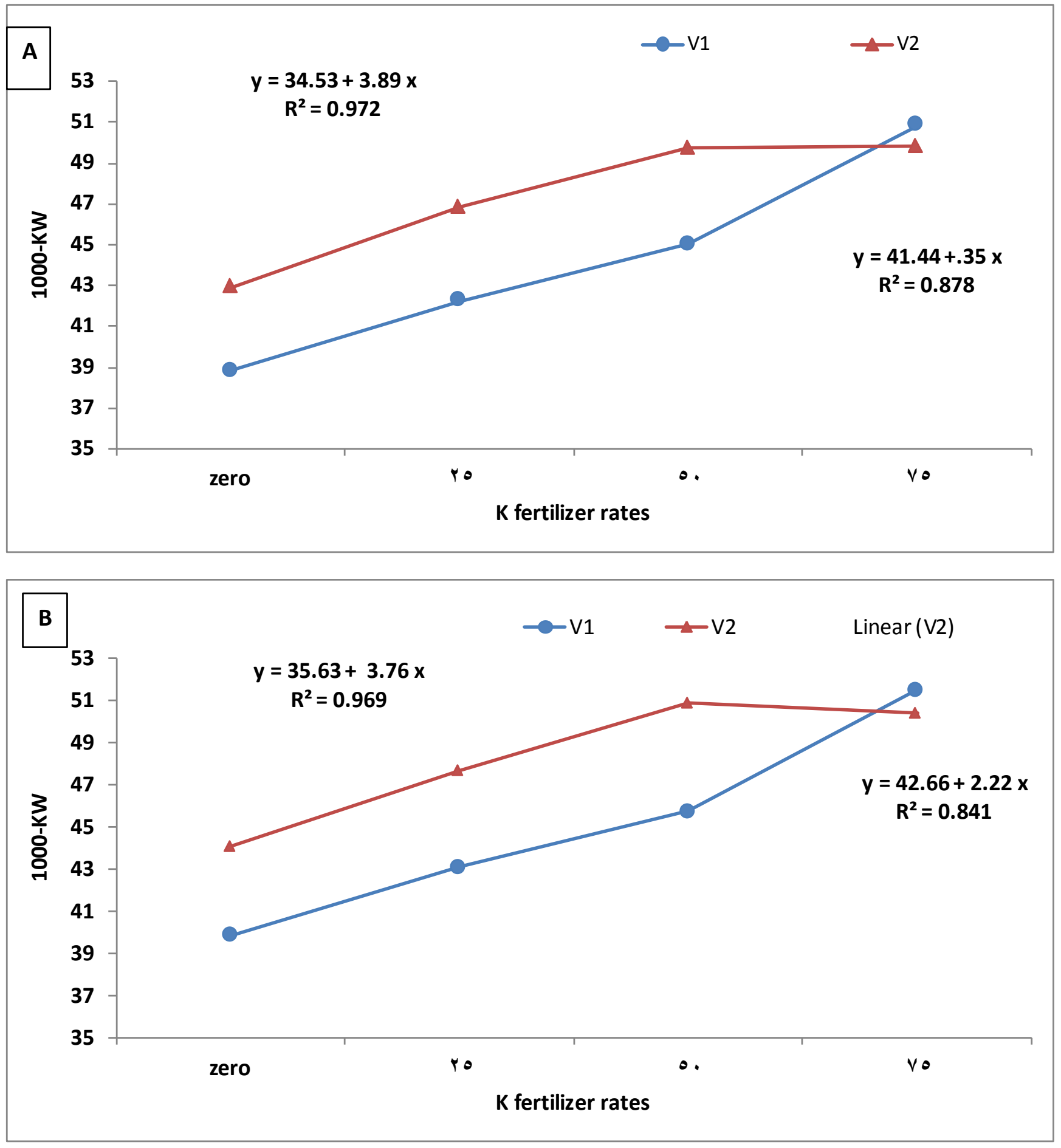

Figure 4. Linear response of 1000-grain weight (g) for V1 and V2 in (A): 2017/2018 and (B): 2018/2019. 
El-HamdiKh H , Omar MM, Mona A EL (2019). Yield and Nutrient Concentrations of Wheat Plants as Affected by the Interaction between Organic Manuers , Phosphorus and Potassium Fertilizers.J. Soil Sci. and Agric. Eng., Mansoura Univ., 10 (2): 99 - 105.

El-Rawy MA (2020). Assessment of genetic diversity for some egyptian wheat varieties based on morphological characters and SSR markers. Scientific Journal of Agricultural Sciences 2 (2): 144-160.

Eman MS, Moustafa MA, Shrshar MS, Shehab El-Din T, Abo Shereef M, Abdel-Majeed S, Abdel-Aleem M, Sabry SR, Hamada A, AboWarda A, Tammam A, Meshref M, El-Sayed E,Ashoush H, Tawfelies M, Hendawy H, Hayam S M, Mostafa A K, El-Borham H, Menshawy A, Moussa A, Wafaa M. El, Koumbor R, Seleem S, Nadia AA, Sharawy G, Abdel-Dayem S, Sohair MH, Swelam A, El-Sawy S, Hammad S, Magda AA, Sabah HA, Khaled MA, Ramadan RA, Amin IA, Zakaria M, Manal AH, Gad-Allah A, El-Maghraby MA, Morad A, Aza MA, Hagras A, Mostafa AT, Mahmoud MS, Mubark MY, Hoda MM, Mahmoud AA, Gomaa A, Enayat G, EMonofy M, Mahmoud S. kh, Hanna N, Moussa MA, Gouda MA, Ageez A, Salem MA, Khattab A, Abdel-Lattif A, El-Hag A,Najwa A, Hefnawy F, Abdel-Samad W, Hassan M A, Yossef EA (2011). Grain yield and stability of the new durum wheat cultivar Bani Suef 6.Journal of Plant Production, Mansoura Univ., 2 (5): 739 - 753,

Fageria NK (2016). The Use of Nutrients in Crop Plants.International Standard Book ,13:978-1-42007510-6

Gul, H, Saeed B, Khan A Z, Latif U, Ali Kh,Rehman J ur,RehmanSur (2012). Yield and yield contributing traits of wheat cultivars in relation with planting dates and nitrogen fertilization. ArpnJournal of Agricultural and Biological Science,7(6): 386-391.

Hamouda HA, El-Dahshouri MF, Manal, FM and Thalooth AT(2015). Growth, yield and nutrient status of wheat plants as affected by potassium and iron foliar application in sandy soil.Int.J. ChemTech Res. 8(4): 1473-1481.

Hasanuzzaman M, Bhuyan MH M B ID, Nahar K, Hossain Md S, Mahmud J A, HossenMd S, Masud AA Ch , Fujita M (2018) Potassium: A Vital Regulator of Plant Responses and Tolerance to Abiotic Stresses. Agronomy , 8, 31; i:10.3390/agronomy8030031.
Khaled MA, Hammad S M (2014).Effect of nitrogen and potassium levels on yield and its components of four new bread wheat cultivars.Journal of Plant Production, Mansoura Univ., 5 (1): 95- 105.

Kubar GM, Talpur KH, Kandhro MN, Khashkhali S, Nizamani MM (2019).Effect of potassium $(\mathrm{K}+)$ on growth, yield components and macronutrient accumulation in Wheat crop.Pure Appl. Biol., 8(1): 248-255.

Maurya P, Kumar V, Maurya KK, Kumawat N, Kumar R, Yadav M P (2014) Effect of potassium application on growth and yield of wheat varieties. The Bioscan, 9: 1371-1373.

Pettigrew WT (2008). Potassium influences on yield and quality production for maize, wheat, soybean and cotton. PhysiologiaPlantarum, 133: 670-681.

Tabatabaei SA, Shams S, Shakeri E, Mirjalili M $R$ (2014).Effect of different levels of potassium sulphate on yield, yield components and protein content of wheat cultivars applied mathematics in Engineering. Management and Technology, 2 (3):119-123.

Upadhyay RG, Ranjan R, Negi PS (2015). Influence of sowing dates and varieties on productivity of wheat under mid-Himalayan region of uttarakhand.International Journal of Tropical Agriculture, 33(2): 1905-1909.

Wang M, Zheng Q, Shen Q, Guo S(2013). The critical role of potassium in plant stress response. International Journal of Molecular Sciences, 14: 7370-7390. 


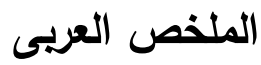

\section{استجابة بعض التراكيب الوراثية لقمح الديورم لمستويات التسميد البوتاسى في الاراضى حليثة/لاستصلاح.}

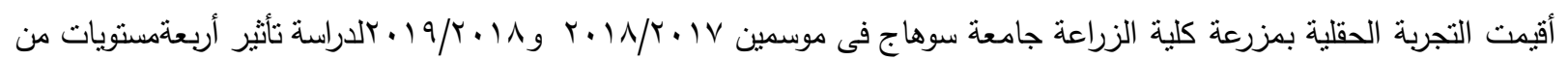

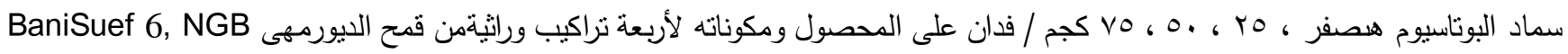
كات أهر 4816 كانت أهم النتائج كما يلى: - وجود فروق معنوية بين مستويات السماد البوتاسي لجميع الصفات المدروسة ما عدا ارتفاع النبات في كلاالموسمين ودليل الحصاد في الموسم الأول فقط.

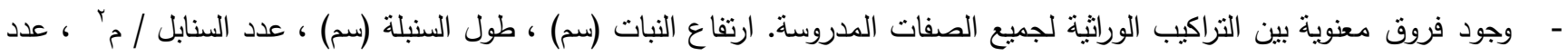

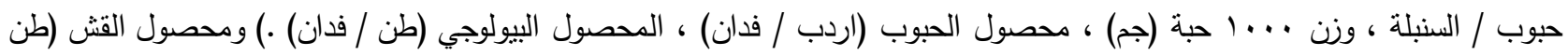

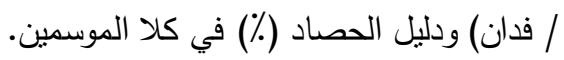
- زيادة التسميد البوتاسى حتى Vo كجم / فدان أدى الى زيادة معنوية فالمحصول ومكوناته في موسمي النموما عدارتفاع النبات (سم) في كلاالموسمين ودليل الحصاد (\%) في الموسم الأول فقط. - اعطى صنف بني سويف 7 والتركيب الوراثى NGB 7214 أعلى قيم لمحصول الحبوب مقارنة بالتراكيب الأخرى في كلا الموسمين. علاوة

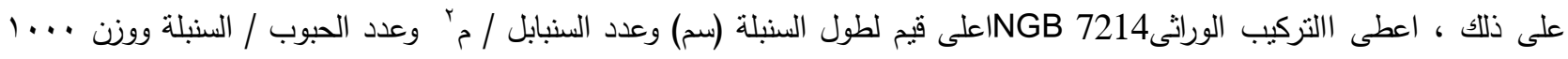
حبة (جم) والمحصول البيولوجي (طن / فدان) ومحصول القش ( طن / فدان) في الموسمين على النوالي • بينما نم الحصول على اطلى اطول

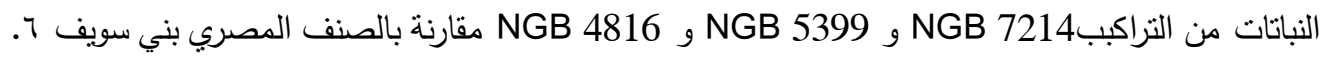

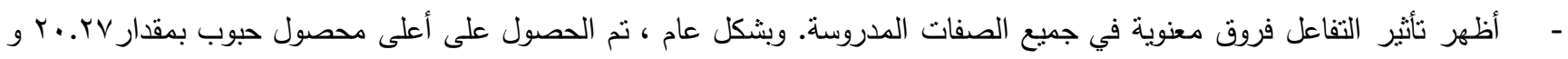

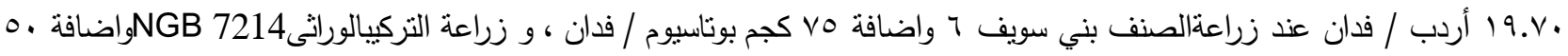
كجم بوتاسيوم/ فدان. على التوالي. كند 